\section{TÖBBLETHALANDÓSÁG A KORONAVÍRUS-JÁRVÁNY MIATT MAGYARORSZÁGON 2020-BAN}

Tóth G. Csaba (KSH Népességtudományi Intézet, tudományos munkatárs), toth@demografia.hu

Jelen cikk a Korfa XXI. évfolyam 2. számában megjelent írás változatlan formában való utánközlése.

\section{ÖSSZEFOGLALÓ}

A koronavírus-járvány 2020 elején jelent meg Európában, és azóta egymást követő hullámokban koncentrálódik az egyes országokban és régiókban. Bár a vakcina megjelenése belátható távolságba hozta a járvány végét, több évnek kell még eltelnie, amíg viszonylag pontos képet kaphatunk arról, hogy az epidemiológiai válság miként befolyásolta a magyar halandósági folyamatokat rövid, illetve hosszú távon. Jelen cikk első lépésként a 2020 -as magyarországi halálozási folyamatokat elemzi, ezen belül pedig a koronavírus hatásainak azonosítását tüzi ki célul.

\section{SUMMARY}

The coronavirus pandemic appeared in Europe on early 2020, and it has been concentrated in successive waves in the individual countries and regions. Although the release of the vaccine has brought the end of the pandemic within a reasonable distance, it still takes several years before we can get an accurate picture on how the crisis has affected the Hungarian mortality in the short and long term. As a first step the present article analyses the Hungarian mortality in 2020, aiming to identify the effects of the coronavirus.

Kulcsszavak: COVID-19 (koronavírus), többlethalandóság Keywords: Covid-19, excess mortality

JEL: C50, I10

DOI: $10.18530 /$ BK.2021.3-4.16

http://dx.doi.org/10.18530/BK.2021.3-4.16
A koronavírus-járvány 2020 elején jelent meg Európában, és azóta egymást követő hullámokban koncentrálódik az egyes országokban és régiókban. ${ }^{1}$ Bár a vakcina megjelenése belátható távolságba hozta a járvány végét, több évnek kell még eltelnie, amíg viszonylag pontos képet kaphatunk arról, hogy az epidemiológiai válság miként befolyásolta a magyar halandósági folyamatokat rövid, illetve hosszú távon. Az alábbi tanulmány ennek megfelelően nem vállalkozhat arra, hogy a járvány egészét vegye górcső alá. A tavalyi év lezárása azonban alkalmat teremt a 2020-as magyarországi halálozási folyamatok elemzésére, ezen belül pedig a koronavírus hatásainak azonosítására.

Egy járvány, vírus vagy bármilyen más, az életkilátásokat érdemben befolyásoló esemény mortalitásra gyakorolt hatását érdemes a demográfiai szakirodalomban gyakran használt többlethalandóság alakulásával mérni. Ennek a mutatónak az a lényege, hogy a valódi halálozási folyamatokat egy hipotetikus (tényellentétes) helyzettel hasonlítjuk össze, amely arra a feltételezésre épül, hogy mi lett volna akkor, ha a vizsgált esemény esetünkben a koronavírus-járvány - nem következik be. Fontos hangsúlyozni, hogy a mutató becslés eredménye, hiszen szükséges hozzá egy prognózis arra vonatkozóan, hogy hányan haltak volna meg 2020-ban abban az esetben, ha a halandóság a korábbi évekhez illeszkedő trendek szerint alakult volna. Ezt összevetve a tavalyi tényleges mortalitási adatokkal megkapjuk a többlethalandóságot.

A mutató két fontos jellemzője közül az egyik, hogy összesítve tartalmaz minden olyan hatást, amely eltéríti a mortalitás alakulását annak korábbi pályájáról. Ez a koronavírus-járvány esetében azt jelenti, hogy egyaránt tartalmazza a közvetlen és közvetett, illetve a pozitív és negatív hatásokat. A közvetlen hatások közé soroljuk azokat az eseteket, mikor egy halálozás visszavezethető a koronavírus-fertőzésre, tehát ha valaki a járvány közvetlen egészségkárosító hatása miatt veszti életét. A közvetett hatások spektruma ennél sokkal tágabb (Beaney et al., 2020). Az egészségügyi rendszer túlterheltsége, a válsággal kapcsolatos pszichológiai ártalmak, a halaszthatónak ítélt kórházi műtétek korlátozása csakúgy, mint a fertőzésveszély miatt elhalasztott vagy végleg meghiúsult orvoslátogatások érdemben növelik az egészségügyi kockázatokat. Mindezen kedvezőtlen következmények hatását mérsékelheti ugyanakkor az egészségügy finanszírozásának növekedése, az általános maszkhasználatnak köszönhető erősebb védelem az influenzával szemben, illetve a különböző balesetek szempontjából kockázatosabb (kültéri) aktivitások korlátozása. Fontos hangsúlyozni, hogy a közvetlen és közvetett hatások közötti választóvonal meglehetősen elmosódott, hiszen nem mindig egyértelmű - különösen a betegség szempontjából leginkább veszélyeztetett idős, illetve krónikus betegek esetében -, hogy kizárólag a koronavírus okoz-e egy-egy halálesetet, vagy más kiváltó tényezők is szerepet játszanak benne. Ráadásul, az egyes országok gyakorlata nem egységes abban sem, hogy miként kategorizálják azokat, akik fertőzöttek ugyan, de más alapbetegségre visszavezethetö a haláluk.

A többlethalandóság mint mérőszám másik fontos sajátossága, hogy a nevével ellentétben valójában nem feltétlenül a többletet, hanem általánosságban az egyenleget 
méri. A mutató lehet negatív is olyan esetekben, amikor a vizsgált évben a halálozások száma valamilyen okból, például az influenzajárvány szokásosnál enyhébb lefutásának köszönhetően a korábbi évekhez képest alacsonyabb. Ahogyan ez hazánkban is történt a vizsgálat tárgyát képező 2020-as év első hónapjaiban.

A többlethalandóság a nevével ellentétben valójában nem fel-
tétlenuil a többletet, hanem általánosságban az egyenleget méri.

A koronavírushoz kapcsolódó magyarországi többlethalandóság kiszámításához a Lee-Miller szerzőpáros (2001) nevéhez füződő sztochasztikus matematikai modell segítségével előrejelzést készítettünk korévenként és nemenként a 2010-2019 közötti tényadatokat felhasználva arra vonatkozóan, hogy miként alakult volna a mortalitás 2020-ban (Tóth, 2021). Ennek a módszernek két fontos előnye van azzal az egyszerübb és emiatt igen elterjedt gyakorlattal szemben, amely csak a megelőző egy-két év korcsoportos halálozási adataihoz, illetve azok valamiféle átlagához méri a tavalyi halálesetek számát. Egyrészt így figyelembe tudjuk venni a halandósági helyzet többé-kevésbé folyamatos javulását: a születéskor várható élettartam például 2010 és 2019 között Magyarországon 74,4 évről 76,2 évre emelkedett. Másrészt ezzel a módszerrel kezelhető a különböző években születettek számának változása is, ami a Ratkó-korszak miatt különösen jelentős a 65 év körüli korosztály esetében. A 60-64 évesek létszáma például 2019 és 2020 között egy év alatt 695 ezerről 651 ezerre, azaz több mint 6 százalékkal csökkent. A halandósági trendek javulása, illetve az egyes generációk létszámában tapasztalható eltérések olyan sajátosságai a hazai demográfiai folyamatoknak, amelyeket érdemes figyelembe venni a többlethalandóság elemzésekor. A 2020 -as év 53 hétből állt, az ezt megelőző évtizedben azonban csupán egy ilyen év volt (2015), ezért az összehasonlíthatóság miatt végig csak az első 52 hetet vettük figyelembe számításainknál.

Modellszámításaink szerint az elmúlt évtized mortalitási folyamatait követve a koronavírus-járvány megjelenése nélkül 2020-ban, 52 hét alatt 128,7 ezren haltak volna meg Magyarországon. Ezzel szemben ténylegesen 139,0 ezer haláleset történt a tavalyi évben. Az éves halálozási többlet ennek megfelelően 10,3 ezer fö. Ahogy azonban erre már utaltunk, torzítja eredményünket az, hogy az elmúlt évtizedre jellemző átlagosan évente 2-3 ezer áldozatot követelő (Pakot-Kovács, 2020) influenzajárvány 2020-ban viszonylag enyhe lefolyású volt, ezért a modellünk erre az időszakra felülbecsülte a várható mortalitást. Annak érdekében, hogy ezt kiszűrjük számításunkból, a nemzetközi gyakorlatnak megfelelően a koronavírushoz kapcsolódó magyarországi többlethalandóságot (továbbiakban: többlethalandóság) attól a héttől (12.) számítjuk, amikor a hivatalos statisztika szerint elhunyt itthon a koronavírus első áldozata (március 16.).
1. ábra: Becsült és tényleges halálozás 2020-ban korcsoportok szerint (fö)

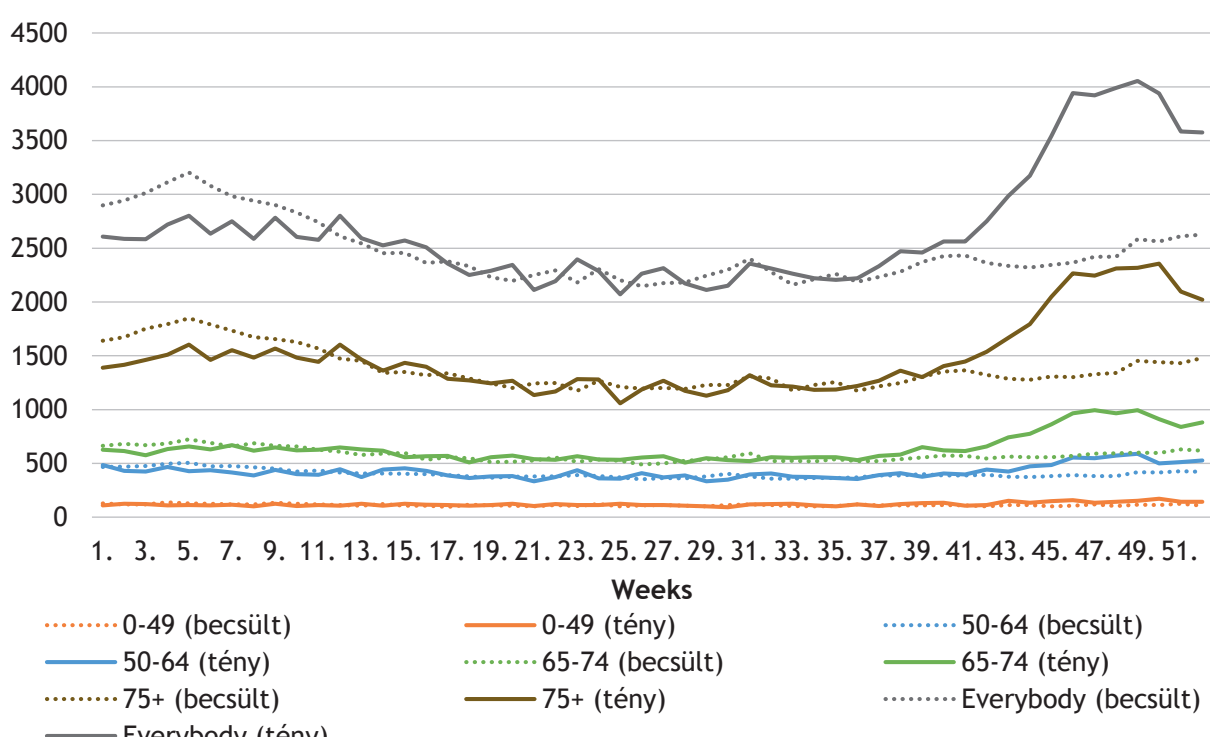

Forrás: Saját számítás a KSH adatai alapján

A 12. és az 52. hét között a többlethalandóság számításaink szerint 13,7 ezer fő volt, azaz összességében a koronavírus megjelenésétől kezdve az év végéig ennyivel többen haltak meg ahhoz a feltételezett helyzethez képest, ha nem lett volna ilyen járvány Magyarországon. Százalékosan kifejezve a magyarországi többlethalandóság mértékét, a legintenzívebb periódusnak számító októberben, novemberben és decemberben 18 , 61, illetve 46 százalékos volt a többlethalandóság. A teljes vizsgált időszakban, azaz március és december között a havi többlethalandóságok átlaga (eltekintve a negatív előjelü hónapoktól) 14 százalék volt. Ez éppen annyi, mint az EUROSTAT erre vonatkozó statisztikai adatközlésében szereplő 22 uniós tagország átlaga. A mutató hat ország (Spanyolország, Lengyelország, Szlovénia, Belgium, Csehország és Bulgária) esetében volt 20 százaléknál nagyobb, és négy országban (Dánia, Finnország, Lettország és Észtország) 6 százaléknál kisebb.

A többlethalandóságra vonatkozó becslésünk szerint az elhunytak 86 százaléka 65 évesnél idősebb, 10 százaléka 50 és 64 év közötti, míg a 49 éves vagy annál fiatalabbak aránya 4 százalék volt. Az elhunyt nők és férfiak száma nagyjából megegyezik, ami két ellentétes hatású folyamatra vezethető vissza. A férfiakra nézve általánosságban nagyobb kockázatot jelent a koronavírus, azonban a legidősebb korosztályokban sokkal 
több a nő, mint a férfi. Mivel a nők születéskor várható élettartama Magyarországon több mint hat évvel magasabb (Kovács-Bálint, 2018), mint a férfiaké, ezért például a 85 év felettiek körében a férfiak aránya csupán 27 százalék. Az említett folyamatokat leginkább a korspecifikus mortalitási ráta képes megragadni (2. ábra), amely a halálozási többletet az adott korcsoporthoz tartozó népesség százalékában mutatja meg.

Ebből az olvasható ki, hogy a férfiak esetében 55-59 éves korban érte el a mortalitási ráta a 0,1 százalékot, tehát e korosztály tagjai közül nagyjából minden ezredik férfi áldozatul esett közvetlenül vagy közvetve a koronavírusnak az általunk számolt többlethalandóság alapján a 12. és az 52. hét között. A mutató innentől meredeken emelkedik, 65 és 70 év között már 0,4, 75 és 80 év között 0,8, 85 év felett pedig 1,8 százalék volt a koronavírushoz kapcsolódó (többlet) mortalitási ráta. A nők esetében alig több mint feleekkora a mutató szinte minden korosztályban: a 65-70-es korosztály esetében 0,2 százalék, a 75-79-es korosztálynál 0,4 százalék, míg a 85 évesnél idősebb nők körében, közelítve a férfiakhoz, 1,6 százalékra emelkedett a korspecifikus mortalitási ráta. Az azonos korcsoporthoz tartozó férfiak és nők többletmortalitási rátája közöti jelentős különbség illeszkedik más országok tapasztalataihoz - Kontopalis és szerzőtársai (2020) például hasonló arányokat találtak, amikor a járvány első hullámának angliai és walesi tapasztalatait vizsgálták.

2. ábra: Korspecifikus mortalitási ráta (százalék, ötéves korcsoportokra)

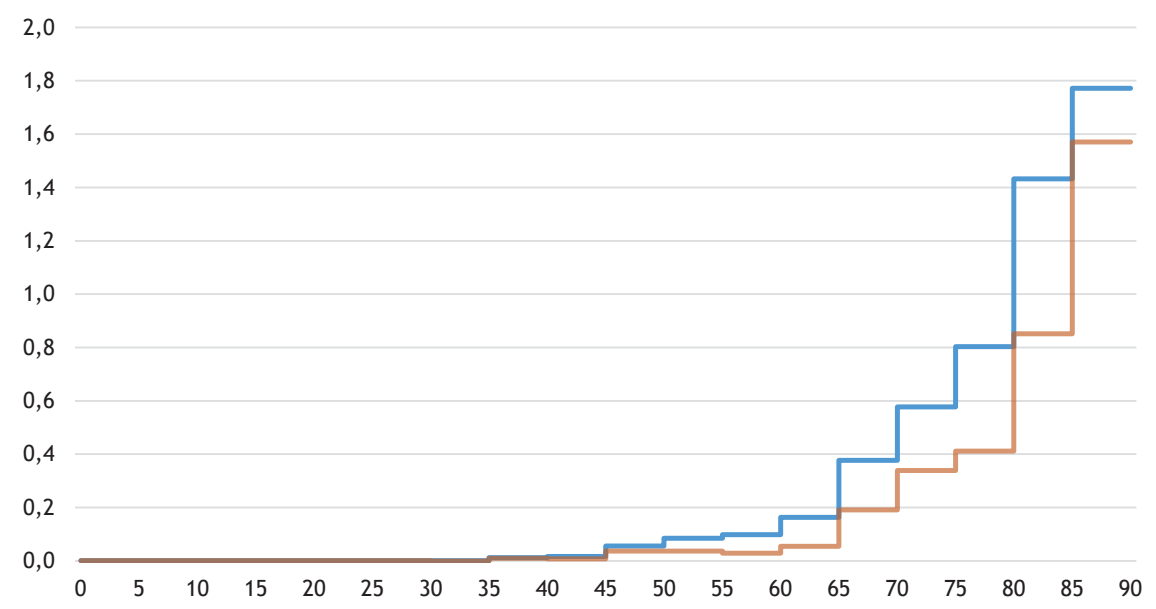

$$
\text { — Férfiak — Nök }
$$

Forrás: Saját számitás a KSH adatai alapján

Az általunk becsült többlethalandóság nagyjából másfélszerese annak, ahányan a hivatalos statisztika szerint elhunytak közvetlenül a koronavírushoz kapcsolódóan 2020-ban. Bár egyelöre nagyon kevés olyan kutatás van, amely alapján összevethetnénk az 1,5-ös magyar elszámolási arányt (undercount rate) más országok adataival, egy nemrég készült tanulmány alapján átlagosnak tekinthető a magyar gyakorlat. Karlinsky és Kobak (2021) a modellezéshez aggregált országos adatokat használtak kor és nem szerinti bontás nélkül, így vélhetően ezzel magyarázható, hogy hazánk esetében a kutatók néhány tizeddel kisebb értéket kaptak. A több mint félszáz országra kiterjesztett elemzésükből ugyanakkor az olvasható ki, hogy ugyan voltak olyan uniós tagállamok, ahol 1 alatt, és olyanok is, ahol 2 felett alakult az elszámolási arány, az EU-s államok többségében 1 és 1,7 között szóródott a mutató, a közösség átlaga pedig 1,5 volt.

A többlethalandóság időbeli lefutása eltérő képet mutat a járvány intenzitásának alakulásáról, mint ami a hivatalos statisztikából kiolvasható (3. ábra). Utóbbi azt jelzi, hogy a második hullám szeptember közepén tapasztalt indulását követően december elején volt a legintenzívebb a vírus hatása Magyarországon, és csak ezután kezdődött egy enyhe mérséklődés. Ez összhangban áll azokkal a véleményekkel, amelyek szerint a november 11-től bevezetett szigorú korlátozások (éjszakai kijárási tilalom, boltbezárások, maszkviselési előírás, középiskolák bezárása) kedvező hatása nagyjából 4-5 hét alatt mutatkozott meg a halálozási adatok kedvezőbb alakulásában. Ezzel szemben számításaink szerint a többlethalandóság felfutása szintén szeptember közepén kezdődött, a tetözés azonban november elejére-közepére tehető, gyakorlatilag arra a hétre, amikor a szigorú korlátozó intézkedések életbe léptek. Ezt követően még közel egy hónapig magas szinten stagnált a heti többlethalandóság, míg az év végére jelentősen, majdnem a felére csökkent. Az eltérő trendek eredménye az is, hogy míg októberben és novemberben a heti többlethalandóság jelentősen meghaladta a hivatalos adatokat, addig ez a különbség teljesen eltűnt az év végére.

3. ábra: A többlethalandóság és a hivatalosan koronavírusban elhunytak számának heti alakulása 2020 utolsó négy hónapjában (fö)

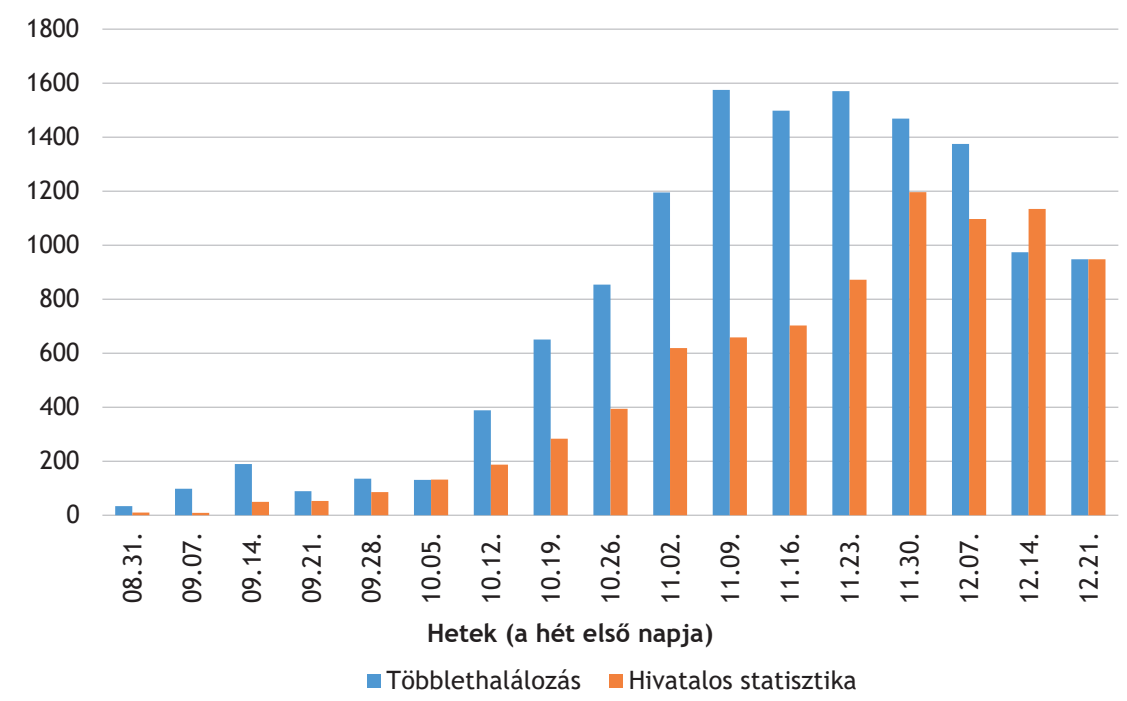

Forrás: Saját számitás a KSH adatai alapján 
A többlethalandóság korai tetőzésének a hivatalos statisztikához képest számtalan oka lehet. Az értelmezés részben attól is függ, hogy mi áll a két adatsor közötti eltérés mögött. Ha úgy tekintünk a különbségre, mint ami lefedi a közvetett halálozásokat, akkor feltehetően az egészségügyi rendszer szűkülő kapacitásának irányában érdemes a választ keresni, hiszen elképzelhető, hogy a rendszer szélsőséges túlterheltsége okozta néhány hétig a hivatalos statisztikán felüli halandóságot. Ha a különbség abból fakad, hogy nehéz egységesen regisztrálni a halálokokat, és valójában a többlethalandóság is jórészt a közvetlen halandóságot méri - csak pontosabban, mint a hivatalos statisztika -, akkor a korai tetőzés megmagyarázható egyebek mellett például a gyógyítási gyakorlat fejlődésével, vagy akár azzal is, hogy a korábban megfigyelt $4-5$ héthez képest rövidebb idő alatt vesztették életüket a járvány halálos áldozatai.

\section{HIVATKOZASOK}

'Köszönettel tartozom Bálint Lajosnak, aki segitséget nyúitott mind az adatgyủitésben mind az eredmények megjelenítésében.

\section{IRODALOMJEGYZEKK}

Beaney, T.; Clarke, J. M; J Jain, V.; Golestaneh, A. K.; Lyons, G.; Salman, D. and Majeed, A. (2020). Excess mortality: the gold standard in measuring the impact of COVID-19 worldwide? Journal of the Royal Society of Medicine, 113(9), pp. 329-334. https://doi. org/10.1177/0141076820956802

Karlinsky, A. and Kobak, D. (2021). The World Mortality Dataset: Tracking excess mortality across countries during the COVID-19

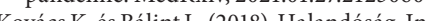

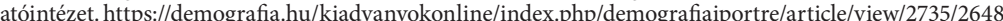
Kovacs K. es Pakot L. (2020). Influenzához kapcsolódó halálozás 2009/2010 és 2016/2017 között Magyarországon. Orvosi Hetilap, 161(23), pp. 962-970. Retrieved from https://akjournals.com/view/journals/650/161/23/article-p962.xm

Kontopantelis, E.; Mamas, M. A.; Deanfield, J., Asaria, M.and Doran, T. (2020). Excess mortality in England and Wales during the Lee, R. C. and Miller, T. (2001). Evaluating the performance of the Lee-Carter method for forecasting mortality. Demography, 38(4), pp. 537-549. https://doi.org/10.2307/3088317

Tóth, Cs. G. (2021). Multi-population models to handle mortality crises in forecasting mortality: a case study from Hungary. Working Papers on Population, Family and Welfare, 36, pp. 1-25. https://doi.org/10.21543/WP.2021.36 